\title{
腸閉塞をきたした虚血性 $\mathrm{S}$ 字状結腸炎の 1 例
}

有田市立病院外科

樫 谷益生河野裕利永井祐吾

\section{A CASE OF ISCHEMIC COLITIS WHICH RESULTED IN OBSTRUCTION OF THE SIGMOID COLON}

Masuo KASHITANI, Hirotoshi KONO and Yugo NAGAI

Department of surgery, Arita City Hospital, Wakayama

1963年 Boley $5^{2)}$, 1966年 Marston ら 3 の報告以来, 大腸の虚血性病変が注目される様 になってきたが, 最近の Brandt ら゙の報告によれば50歳以上の大腸炎患者のちちでは， 虚血性大腸炎はその74\%をしめているとい5．我国です最近 4〜5年間に報告例が急增 してきている，しかし本邦報告例の多くは，一過性型か軽度の狭窄型の虚血性大腸炎で ある．取近我々は，68歳の男性で発症11カ月後に高度の腸管狭窄をきたし，腸閉塞症状 を呈した，虚血性 S 字状結腸炎を絓験し，㹟窄部晹管切除を施行しこれを治密せしめた ので報告する。

䍘引用語： 3 カ月以内

\section{藉}

虚血性大腸炎は, 1963年 Boley $5^{22}$ か，腸間膜の主幹 動静脈に明らかな閉塞がないにもかかわらず，乫発す る腹痛と下血で発症し注腸検查で大腸に拇指王痕像が みられ，自然治霜した 5 症例を発表し，さらに1966年 Marston ら'が同様な症例を16例集計し，これをIschemic colitis（虚血性大腸炎）と命名したことにより 注目されるよらになった。 Marston らは本疾患を重症 度により，壊死型，狭窄型および一過性型の 3 つに分 類した，本邦報告例の多くは 1 過性型か軽度の狭窄型 であるか，最近我々は発症11力月後に高度の腸管狭窄 をきたし腸閉塞症状を呈した虚血性 S 字状結腸炎を 経検したので，若干の文献的考察を加えて報告する。

\section{症 例}

患者：68葴，男性

主訴：左下腹部痛ならびに下血

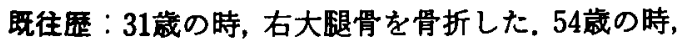
痛風発作があり加療した，60歳の時より紡尿病の加療 をしていた。66歳の時，右大駺骨骨髄炎で手術を受け た.

家族歴：特記すべき事はない。

現病歴：1980年12月27日昼頃, 歩行中突然持続性の
左下腹痛が出現し，約 3 時間後に新群血下血があり， 当院内科を受診した。

初診時現症：体格中等度，顔面や小荅白であるが， 全身状態は良好. 体温 $36.5^{\circ} \mathrm{C}$ ，脈拍は $90 /$ 分で不整なく 緊張良。眼䀫結膜に貫血を認めず，眼球結膜にも黄疸 を認めない，左下腹部に压痛を認めたが，筋性防御等 は認めなかった，直腸指診では指粪に新鮮血の付着が あった。

臨床経過：外来にて鎮痛剤を投与した所，疼痛は少 し軽快したので帰宅させたが，左下腹部痛は同日午後 10時頃まで持続し，その後数日間は，1 日20行前後の 裹急後重があった。発症後18日目に当院内科を再受診 したので直腸鏡検查を行った所，肛門より $10 \mathrm{~cm}$ 以上 口側の下部 S 字状結腸は全周性に軽度㹟窄を来たし， 粘膜は高度に浮腫状で易出血性であった。この時の諸 検查では，血糖 $120 \mathrm{mg} / \mathrm{dl} ， \mathrm{CRP}$ が $5(+)$ を呈した以 外には異常はなかった。この頃には患者の自覚症状す ほとんど消失し，生検結果です悪性所見を認めなかっ たので，定期的に注腸検查を行い，経過を観察する事 にした。

その後無症状に释過していたが, 発症後 7 カ月目頃 より，便柱狭少および排便回数の増加を訴えるように 


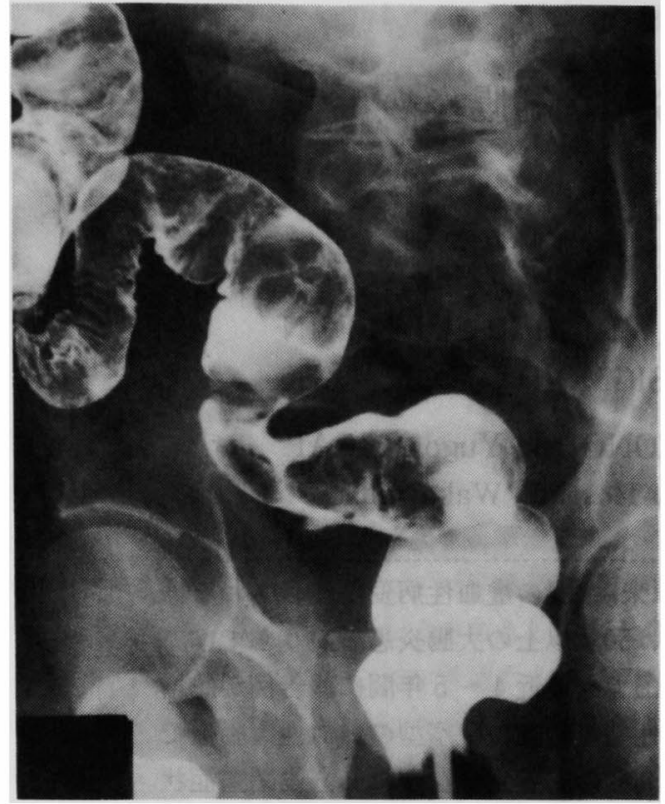

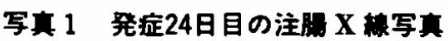

なり，その症状が徐々に増強してきた，発症後11カ月 目には, 腹部膨満と呕吐が出現し, 腹部単純 X 線像で 大腸および小腸に著明なガス詝留が認められた（写真 4). 直腸鏡および注腸 X 線検查にても高度の㹨窄が 認められ，手術適応があると判断され当外科へ紹介さ れた。

注䨎X線および直腸鏡所見：発症後24日目に第 1 回注腸検查を行った(写真 1 )。下部 S 字状結腸に約 10 $\mathrm{cm}$ にわたる伸展不良部があり，拇指圧痕像に似た所 見がみられた，伸展不良の中央部には，深い潰禓形成 を思わせる腸管壁よりのパリウム突出像もみられた。

発症後27日目に行った直腸鏡検查では，下部 S 字状 結腸は全体に伸展不良で, 粘膜は浮腫状で白苔を有す る溃場が喼められた。

発症後35日目に第 2 回注腸検査を行ったか（写真 2), 下部 S 字状結腸は蛇管状に狭窄し, その辺縁は不 整で，粘膜のレリーフ像には，大小不同の小結節状の 陰影が認められた。正常部との境界は比較的明暸で あった。

発症後 3 力月半目に第 3 回注腸検査を行ったか（写 真 3). 下部 S 字状結腸に前回とほぼ同様の病变が認 められた。しかし病变部の範囲は少し短縮してきたと 思われた。

写真 5 は発症11力月目の注腸検查であるが，辺縁の きわめてなめらかな高度の狭窄が認められ，直腸鏡検

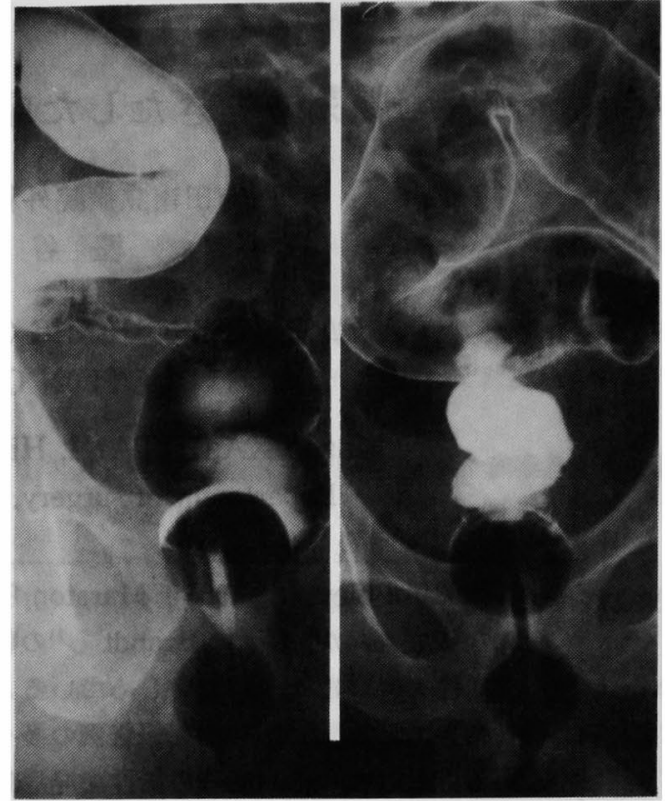

写真 2 発症35日目の注腸 X 緗写真

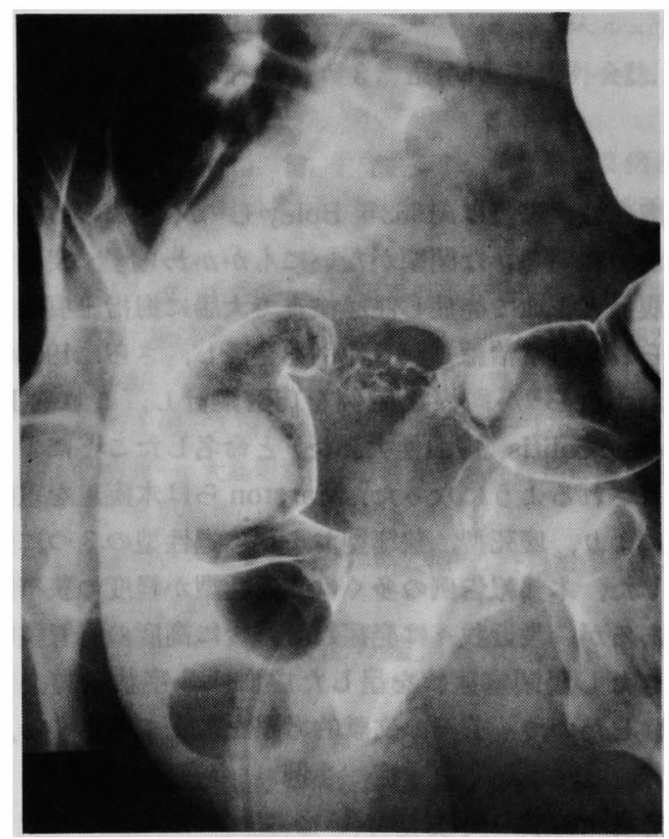

写真 3 発症 3 カ月半目の注腝 $\mathrm{X}$ 線写真

查を行ったところ, 肛門より約 $15 \mathrm{~cm} の S$ 字状結腸に 内腔の直径が約 $5 \mathrm{~mm}$ の高度の狭窄が認められた。

手術所見：全身麻酔下に開腹すると腹水はなく, 䀒 脾にも異常を認めなかった。下行結腸は異常なく、下 部 S 字状結腸に浆膜面のひきつりをともなう狭窄部 


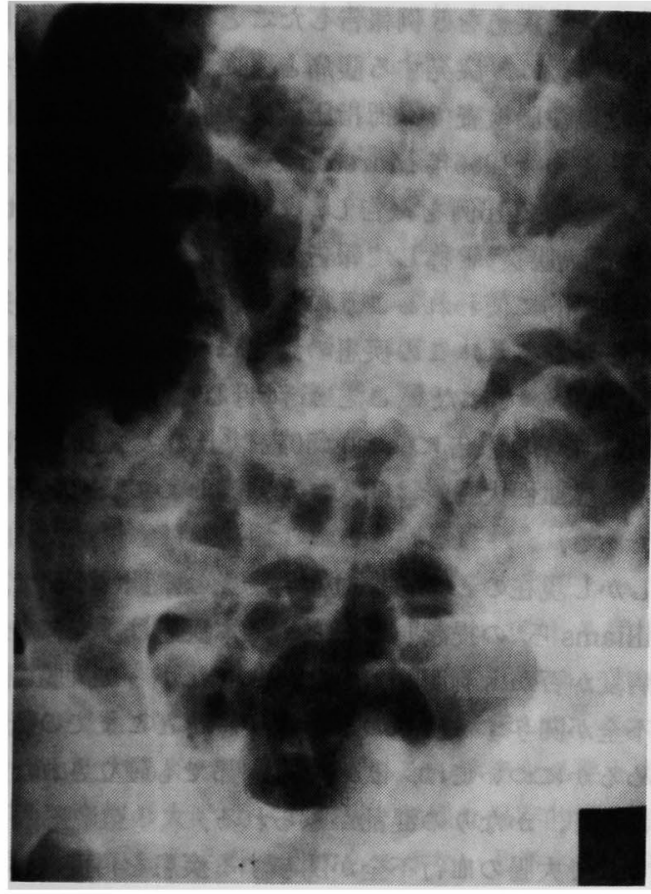

写真 4 発症11カ月目の腹部単純 X 線写真

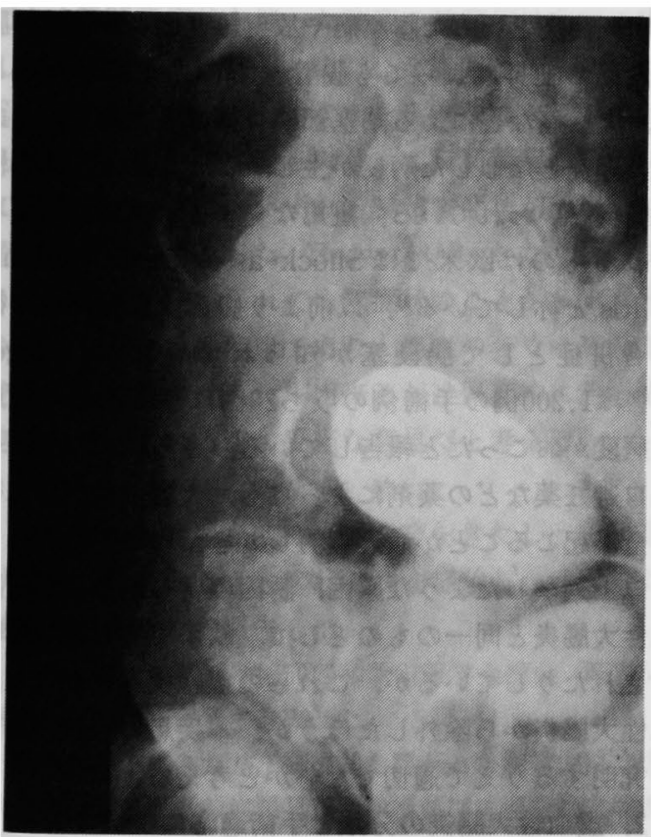

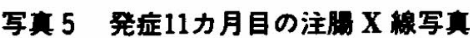

を認めた(写真 6 )。同部の腸間膜の動静脈に異常はな く、リンバ節の腫張も認めなかった。㹟窄部を中心に S字状結腸を約 $7 \mathrm{~cm}$ 切除し Gambee 法で端々吻合し
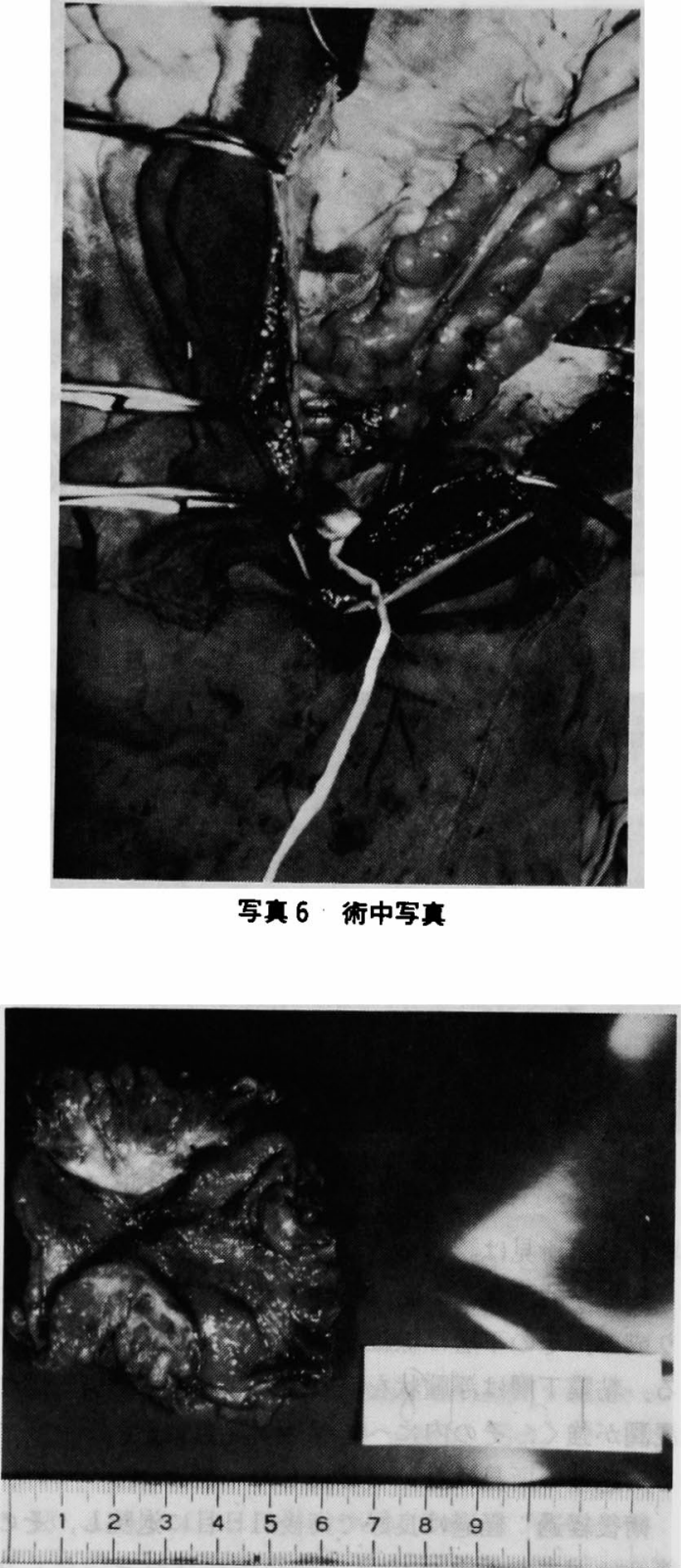

写真 7 切除橴本写真（全体像）

た.

切除標本肉眼所見：切除結腸のほぼ中央に限局した 高度の狭窄を認める，粘膜面は色調には変化はないが

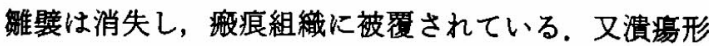
成も認めない。㹟窄部の中央に直径的 $2 \mathrm{~mm}$ の山田 II 型の小ボリープを 1 コ認める(写真 7)。割面では狭窄 部を中心に粘膜下層に高度の線維化を認めるが悪性を 


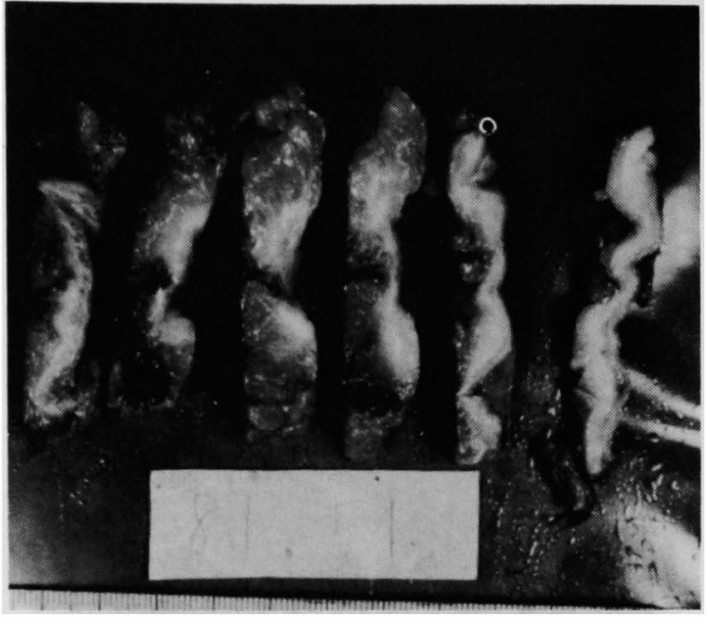

写兵 8 切除标本写真（割面像）

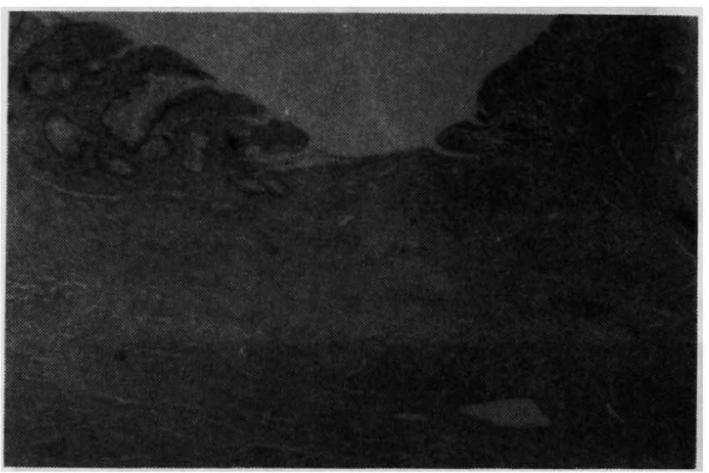

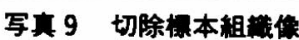

疑わせる所見は認められなかった（写真8）.

組裁学的所見：表面は一部で粘膜欠損し肉芽組織上 り成る。その下層は線維組織が筋層を越え浆膜に達す る. 粘膜下層は浮腫状を呈し、リンパ球，形質細胞の 浸渭が強く，その内にへモジデリン領食細胞が混在す る. 悪性の所見はない(写真 9 ).

術後経過：経過は良好で術後21日目に退院し，その 後 8 力月後の現在まで患者の腹部症状はまったくな い.

\section{考案}

1. 虚血性大腸资の概念について

大腸の虚血性病变としては，古くから腸間膜動静脈 閉塞に基つく腸硬塞ないし腸壊死が代表的なるのとし て上く知られている。これらは肉眼的に判定しらる病 变である.これに対し虚血性大腸炎といら概念は, 1963 年に Boley ら ${ }^{211}$ が主幹動静脈に明らかな閉塞がない にもかかわらず，腸管の虚血に起因すると考えられる
急性の大腸疾患を 5 例報告したことに始まる，その臨 床像の特徵は, 突発する腹痛之下血で発症し, 発症後 間もない注腸検査では拇指压痕像が認められることで ある，その後1966年 Marston ら ${ }^{33}$ か，同様の症状と注 腸像を呈する16例を報告し，これをIschemic colitis （虚血性大腸炎）と称して報告したことにより，この名 称が一般的に使われるようになった。 その後多くの症 例報告がなされ，この疾患の頻度については，けっし て稀なるのではないことが判明してきた。最近の Brandt ら"の報告によれば50歳以上の大腸炎患者81 人中, 虚血性大腸炎は60人（74\%）しめていたとのこ とである。

しかし現在のところ虚血性大腸炎の本態は不明で, Williams ら4の提起したごとく，本疾患は本当に虚血 性病変か否かも判明していない. したがって大腸の血 行不全が関与する疾患のらち本疾患をどこまでの範囲 含めるかについては, 欧米です本邦です確立された定 説はなく，かなりの混乱がみられる。

ここで大腸の血行不全か関与する疾患を再度検討す ると, 主幹動静脈の閉塞以外にも多くの疾患が列举さ

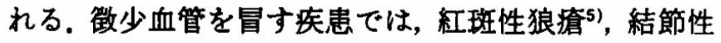
動脈周囲炎といった膠原病や放射線性腸炎がある，腸 管内压の上昇によっても腸管壁での血流障害が起こ り，大腸癌などによる閉塞部の口側に 2 次的に，虚血 性大腸炎と類似した病変が生じることがあり, 閉塞性 大腸炎といわれている．重篤なショックに随伴してみ られるすのは欧米ではShock-associated ischemic colitis と称している9!. 以前より腹部大動脈疾患の術 後合併症として腸硬塞が知られていたが Ottinger $5^{10)}$ は1,200例の手術例の5ち20例に左側結腸の虚血 性病变が括こったと報告している。ささらに抗生物質や 経口避妊薬などの薬剤によっても，大腸の局所に血行 不全が起こることが最近判明してきた

以上列举したような原因, 誘因の明らかな疾患も虚 血性大腸炎と同一のものとして，欧米でも日本です報 告されたりしているが，これらの類縁疾患はやはり虚 血性大腸炎から除外したほらが，本疾患の今後の本態 を究明するらえで商切でないかと考える。

\section{2. 虚血性大閶炎の分類と手術適応にっいて}

虚血性大腸炎は Marston らの重症度による分類に 従って，壊死型，㹟窄型および一過性型とに分けられ る. その各々の頻度について考えてみると，欧米では Marcuson ら ${ }^{15)} 122$ 例のうち，壊死型は12\% (15例), 㹟窄型は $48 \%$ （58例）一過性型は36\% (44例) で不明 
は4\%(5 例)であった。本邦では竹本ら ${ }^{16)}$ が45例を集 計しているが，燷死型は13\%( 6 例)，㹟窄型は $18 \%$ ( 8 例）で一過性型が69\%（31例）であった，虚血性大腸 炎の壊死型は腸管壁の全層が障害されることにより起 こり，発症後数時間から $2-3$ 日以内に腹膜炎症状中 ショック症状が出現してくるので，他の 2 つの型即ち 扶窄型と一過性型とは臨床的に容易に鑑別できる，㹟 窄型は粘膜下居・内輪筋層か障害されることにより起 こり，一過性型はほは粘膜層に限られた範囲だけが障 害されることにより起こるが，この両者の鑑別は発症 当初は困難である. Brown ${ }^{17}$ は㹟窄型と一過性型の虚 血生大腸炎を17例集計し，その臨床症状を比較検討し ているか，発症当初の症状が強いから狭袏型とか，弱 いから一過性型とかいった傾向はなく，むしろ症状の 持続期間が数日以内と短いすのは一過性型で，それ以 上長びくののに㹟菅型が多かったと報告している。

虚血性大腸炎の墙死型はるちろん手術を必要とする か，㹨窄型の大半は一過性型と同様な保存的漟法の及 で十分軽快し，手術適応はあまりないと考之る，狭窄 の程度について文献的に検討すると，軽度ないし中等 度の伸展不良や变形成をきたすすのが大半で自跧例の ごとく嗞閉塞症状を伴った高度の狭窄例は非常に稀に しかみられず，自倹例と類似した症例は，欧米ではO' Connell $5^{18)}$ の報告した発度後 6 カ月に本邦では大岩 $ら^{201}$ の報告した発症後 1 力月半に, 又教室の廣田ら ${ }^{191}$ の発症後 8 カ月に。、い゙れも腸閉塞症状が出現した症 例があるのみであった。 Brownは17)，かなり強い狭窄 か注腸検査で認められてす無症状のことが多く, 病变 が進行しない良性疾患であり，患者の多くは高龄者で あることを考虑に入れ，出来るだけ保存的に治療すへ きたと述べているが，妥当な意見だと考える。

$$
\text { まとめ }
$$

発症11カ月後に高度の腸管㹟窄をきたし，腸閉塞应 状を呈した，虚血性 S 字状結炎を経験し，手術により 治零せしめたので報告した。

な㧍本論文の要旨は第50回和歌山医学会総会（昭和57年 8月：田辺市）に於て亜表した。

稿を終わるにあたり，御校閲を賜わった和歌山県立医科 大学消化器外科学教室腾見正治教授並びに河野啺之助教授 に深辢の意を表します。

\section{文 献}

1) Brandt, L., Boley, S., Goldberg, L., et al. : Colitis in the elderly. Am. J. Gastroenterol., 76 : 239-245, 1981.
2) Boley, S.J., Schwarz, S., Lash, J., et al.: Reversible vascular occlusion of the colon. Surg. Gynec. Obstet., 116 : 53-60, 1963.

3) Marston, A., Murray, T., Pheils, M., et al. : Ischaemic colitis. Gut, 7:1-15, 1966.

4) Williams, L.F. and Wittenberg, J.: Ischemic colitis: An useful clinical diagnosis, but is it ischemic? Ann. Surg., $182:$ 439-448, 1975.

5）五閏謹秀, 望月孝規, 中根 弘他：Systemic Lupus Erythematosusの経過中にいわゆる急性のIschemic Colitis を起こした 1 例一いわ仍る血管资 との関係についてての病理組諓学的梌討一。胃之腸, $14: 637-644,1979$.

6）家田勝幸, 勝見正治, 浦 伸三他：放射線腸炎の外 科的治療. 日外宝画，49:112-118，1980.

7) Glotzer, D.J., Roth, S.I. and Welch, C.E.: Colonic ulceration proximal to obstructing carcinoma. Surgery, 56 : 950-956, 1964.

8）山本真二，家田勝幸，山口䭛郎他：Obstructive Colitis の 4 例. 日臨外会誌, 43：816-821, 1982.

9) Sakai, L., Keltner, R. and Kaminski, D. : Spontaneous and shock-associated ischemic colitis. Am. J. Surg., 140 : 755-760, 1980.

10) Ottinger, L.W., Darling, R.C., Nathan, M.J., et al. : Left colon ischemia complicating aortoiliac reconstruction. Causes, diagnosis, management, and prevention. Arch. Surg., 105: 841 -846, 1972.

11) McKinley, M.J., Troncale, F., Sangree, M.H., et al. : Antibiotic-associated colitis: Clinical and epidemiological features. Am. J. Gastroenterol., 77: 77-81, 1982.

12) Bogomoletz, W.V.: Fibrin thrombi, a cause of clindamycin-associated colitis? Gut, 17: 483 $-487,1976$.

13) Arnold, G.L., Fawaz, K.A., Callow, A.D., et al. : Chronic intestinal ischemia associated with oral contraceptive use. Am. J. Gastroenterol., $77: 32-34,1982$.

14) Kilpatrick, Z.M., Silverman, J.F., Betancourt, E., et al.: Vascular occlusion of the colon and oral contraceptives. Possible relation. N. Engl. J. Med., 278 : 438-440, 1968.

15) Marcuson, R.W. and Farman, J.A.: Ischaemic disease of the colon. Proc. roy. Soc. Med., 64 : 1080-1083, 1971. 
16）竹本忠良, 川井啓市, 渡辺正俊他：虚血性大腸㷋の 臨床. 胃と䁑, $16 ： 259-265,1981$.

17) Brown, A.R.: Non-gangrenous ischaemic colitis. A review of 17 cases. $\mathrm{Br}$. J. Surg., $59: 463$ $-473,1972$.

18）展田耕二, 松本孝一, 浦 伸三他：若年者の阻血性 得炏かと思われる 1 症例. 外科，39:833-836，
1977.

19) O'Connell, T.X., Kadell, B. and Tompkins, R. $\mathrm{K}$. :Ischemia of the colon. Surg. Gynec. Obstet, $142: 337-342,1976$.

20）大岩俊夫, 杉町圭葴, 下田悠一郎他：発症より経過 観察しえた虚血性腸炎の 1 手術例. 胃と腸，16： 315-318, 1981. 